Article

\title{
Farmers' Knowledge, Perception and Practices in Apple Pest Management and Climate Change in the Fes-Meknes Region, Morocco
}

\author{
Alieu Moinina ${ }^{1}$, Rachid Lahlali ${ }^{1, *(\mathbb{C})}$, Dustin MacLean ${ }^{2}(\mathbb{D})$ and Mohammed Boulif ${ }^{1}$ \\ 1 Department of Crop Protection, Phytopathology Unit, Ecole Nationale d'Agriculture de Meknès, BP/S 40, \\ Meknès 50001, Morocco; malieu@enameknes.ac.ma (A.M.); mboulif@enameknes.ac.ma (M.B.) \\ 2 Department of Plant Agriculture, University of Guelph, 50 Stone Road East, Guelph, ON N1G 2W1, Canada; \\ dmacle02@uoguelph.ca \\ * Correspondence: rlahlali@enameknes.ac.ma or lahlali.r@gmail.com; Tel.: +212-55-30-02-39
}

Received: 9 October 2018; Accepted: 11 November 2018; Published: 20 November 2018

\begin{abstract}
Apple production in the Fes-Meknes region of Morocco is highly affected by pests and adverse weather conditions. A survey of apple farmers' knowledge, perceptions and practices (KPP) in pest management and climate change was conducted in spring 2018 in two major apple-producing provinces of the region. Each farmer reported three insect pests and two diseases on average affecting their orchards. Pest management was performed by a combination of cultural and chemical methods. All farmers used dormant chemical sprays. About $60 \%$ of the respondents adopted pest surveillance based on visual inspection and $41.9 \%$ chose their pesticides on the basis of the information received from pesticide sellers. An average of 20 treatments per year was applied in each orchard. Regression analysis showed that neither the age of apple trees nor the number of pesticide applications influenced yield. Adverse weather conditions affected all apple plantations and the most frequent problems perceived were frosts, hailstorms, hot winds and water shortage. Of the orchards reported, 51.3\% were protected with anti-hail nets. In order to reduce the rate of pesticide applications, better information on integrated pest management is required. Introduction of organic farming is necessary as $40.5 \%$ of the farmers agreed to convert to this practice in the future provided that market facilitation is established.
\end{abstract}

Keywords: apple orchards; farmers' KPP; integrated pest management; climate change; Fes-Meknes region

\section{Introduction}

Apple production plays a vital socio-economic role in the Fes-Meknes region of Morocco. It is the main source of income for a large segment of small and medium-sized farmers in mountainous areas where tree crops are most adapted to the edaphoclimatic conditions. The region accounts for nearly $38 \%$ of Moroccan apple production and $34 \%$ of the country's cultivated area. This sector generates 3 million working days, and about MAD 10 billion (USD 1.05 billion) of turnover for the country [1].

An apple tree needs a cool winter to meet chilling requirements for dormancy-break. Mild temperatures in the summer and cold temperatures in the winter of the High and Middle Atlas mountain range in the Fes-Meknes region provide favorable climatic conditions for the production of apples. In addition, provinces with mild winters have potential for extension of apple production with new varieties having low chilling requirements [2]. Thus, the first apple plantations in Morocco were probably established during the 1920s from Spanish cultivars with low chilling requirements as the apple production areas in Morocco are located in the high altitudes of the region [1,3]. 
The Fes-Meknes region is characterized by the diversity of its soils ranging from volcanic ash to Triassic clays and from primary schist to alluvial deposits. These soils present high potential for agricultural production in the region. Considering the climate, the region is characterized by a continental climate in the North, cold and humid conditions in the mountainous areas, and a semi-arid climate in the highlands of Missour [4]. It should also be noted that this climate variability leads to a diversity of crops that adapt to the specificities of this region.

To strengthen the economy, the apple production sector receives support and incentives from the government within the framework of the contract program between the government and the Federation of the Development of Arboriculture in Morocco (FeDAM) for the period from 2011-2020. The contract program is aimed at improving the development of the sector by increasing production, promoting and improving valuation conditions of apples, developing aggregation projects around recovery units and strengthening professional organizations associated with the sector [5].

Despite all these advantages, apple production is faced with many constraints, especially pests and adverse weather conditions. The major constraints that hinder the progress of the sector are frosts, hailstorms and hot winds coinciding with the critical stages of plant growth. However, the sector also lacks proper management practices and market facilitation [6]. The constraints related to farm management practices could be overcome by upgrading farmers' knowledge, perceptions and practices in pest management. Worldwide, apples are subject to a large number of diseases caused by pathogenic fungi, bacteria, and other phytopathogens [7].

In Morocco, apple disease management is expensive because of the high number of pesticide applications that this crop requires. Furthermore, pesticide application depends on the situation of each orchard and the particular pest outbreaks. This makes it difficult to establish a calendar-based treatment protocol [8]. The use of chemical inputs has raised concerns as consumer awareness increases.

The impacts of climate change on agriculture are becoming increasingly important in the region. Apple production decreases significantly due to temperature and rainfall fluctuations. In Morocco, adverse weather conditions are one of the major issues that hinder apple production [9]. For instance, in Draa-Tafilalet, which is the neighboring region of Fes-Meknes, apple production decreased by $40 \%$ in 2016 [10]. This decline in production was due to unfavorable weather conditions and the alternation in the productivity of the trees.

Keeping in view the issues of pests and weather changes for apple production, our survey focused on apple farmers' decision-making, knowledge, perceptions and practices in managing these issues. The information was used to (i) evaluate the pests and climate change issues that farmers perceive as most important and (ii) to characterize farmers' knowledge, perceptions and practices in apple pest management as well as their adaptation practices towards climate change in Ifrane and Sefrou, in the Fes-Meknes region of Morocco.

\section{Materials and Methods}

\subsection{Study Area}

Two major apple-growing provinces, namely Ifrane and Sefrou (Figure 1) in the region of Fes-Meknes, Morocco, were surveyed during this research. In terms of distribution of area of apple production in the region, Ifrane province accounts for about $45 \%$ followed by Sefrou province $(28 \%)$, while the remainder is situated in the El Hajeb and Boulemane provinces in the same region [1].

The region is characterized by a climate ranging from Mediterranean to continental with cold winters and hot summers. Fortunately, cold and humid weather, very snowy in winter and temperate in summer, favors apple production in this mountainous area. The mean annual rainfall across the region varies from one province to another and from season to season [4]. In Ifrane province, the total annual rainfall varies between 350 (in the south-west) and $1100 \mathrm{~mm}$ (in the north-east). Snowfall occurs sporadically from December to April with varying amounts ranging from 20 to $60 \mathrm{~cm}$. The variation of precipitation calls for irrigation of the orchards. The minimum and maximum temperatures recorded 
during the past 10 years were $-24^{\circ} \mathrm{C}$ and $+37^{\circ} \mathrm{C}$, respectively [11]. In Sefrou province, the average annual rainfall is about $460 \mathrm{~mm}$, average annual temperature is $16^{\circ} \mathrm{C}$ with an average maximum of $25^{\circ} \mathrm{C}$ and a minimum of $9.5^{\circ} \mathrm{C}$. The hot and dry prevailing winds blow during the summer in the north-northeast direction [12].

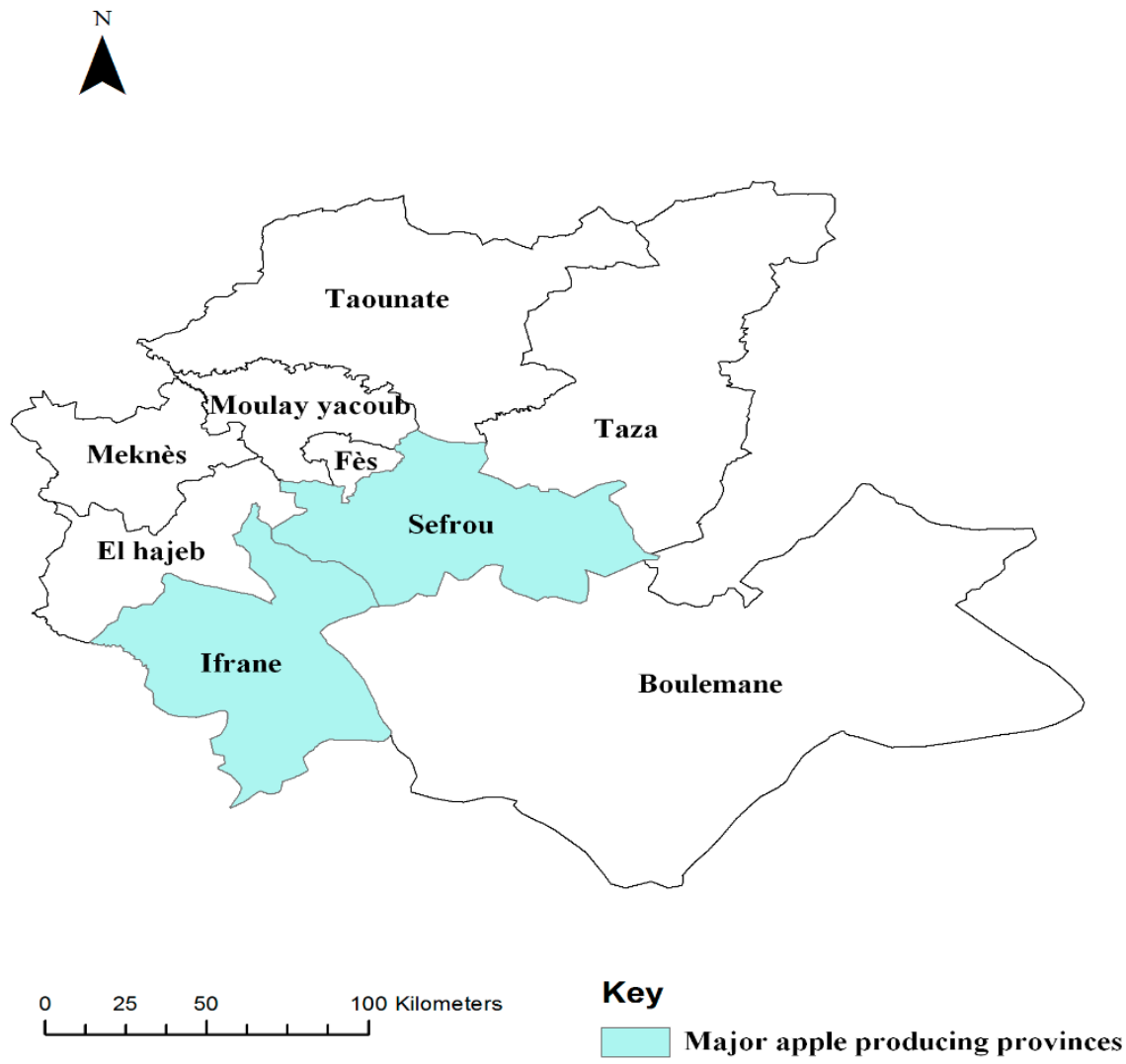

Figure 1. Map showing the study area, and highlighting Ifrane and Sefrou, the main apple-producing provinces of the Fes-Meknes region.

\subsection{Survey}

A survey was conducted from April to June 2018 in Ifrane and Sefrou, the two major apple producing provinces in the Fes-Meknes region. Snowball sampling, which involved the apple farmers helping us to identify or locate their colleagues, was adopted in each of the provinces. A total of 46 apple farmers from seven communes were interviewed (Table 1).

The questionnaire was designed to provide information on general characteristics of apple farmers and their orchards. It also aimed to assess agronomic and pest management tactics, and the impacts of climate change on yield quality and quantity. Farmers' knowledge, perceptions and practices (KPP) related to pests, natural enemies and pest management received special emphasis. The content of the questionnaire and the type of questions asked were agreed upon after key informant interviews. To evaluate farmers' perceptions of pests and diseases, we had to take into consideration the major pests of economic importance in apple trees. Perceptions of adverse weather conditions were highly considered because of the impacts of climate change on apple production in the region. Furthermore, questionnaire-based discussion with the farmers also highlighted these issues. This discussion consisted of both direct and indirect questions that elicited the respondent's utilization, knowledge, and adaptation practices for the existing conditions in apple production. 
Table 1. Apple orchards represented and number of farmers interviewed in the Ifrane and Sefrou provinces of Morocco from April to June 2018.

\begin{tabular}{ccc}
\hline Province & Commune & Number of Apple Farmers Interviewed \\
\hline \multirow{4}{*}{ Ifrane } & Tigrigra & 8 \\
& Dayet Aoua & 3 \\
& Ain Leuh & 8 \\
& Sidi El Makhfi & 3 \\
& Timahdite & 3 \\
\hline \multirow{2}{*}{ Sefrou } & Ait Sbaa & 12 \\
& Laanoucer & 9 \\
\hline
\end{tabular}

\subsection{Statistical Analysis}

Survey data were encoded, and statistical analysis was accomplished using SPSS statistical software (version 20). Percentages were based on the number of respondents and where multiple responses were obtained, total sample size was used. Based on the questionnaire and the information collected, both parametric and nonparametric tests were conducted.

\section{Results}

\subsection{Farm and Farmer Characteristics}

Table 2 shows the basic characteristics of apple farmers and their orchards in the provinces of Ifrane and Sefrou. The age of the apple orchard owners ranged from 22 to 80 years and $55 \%$ of respondents in Ifrane were over 40 years old. Of the farmers interviewed, 37.2\% did not pursue formal education, $31.4 \%$ stopped at primary school and $20.0 \%$ at secondary school, whilst $11.4 \%$ attained a tertiary education level. Nonetheless, more orchard owners in Ifrane pursued formal education than those in Sefrou. There was little association between the level of education and the provinces. Moreover, there was no significant difference in farmer age or education level between the provinces (Cramer's $\mathrm{V}=0.139, P>0.05$ ). Almost all the apple farmers interviewed owned their orchards (proprietor).

The age of apple orchards was between 4 and 40 years. The age of certain apple orchards was problematic as some of the orchards were entering the age of senescence. Among the respondents in the two provinces, over $20 \%$ of the orchards were more than 20 years old. Orchards from Ifrane and Sefrou that were less than 10 years old comprised $55.6 \%$ and $25.0 \%$ of the provincial totals, respectively. There was a strong association between the two provinces.

Table 2. Basic characteristics of apple farmers and orchards in the provinces of Ifrane and Sefrou.

\begin{tabular}{lccc}
\hline Characteristics & \multicolumn{2}{c}{ Province } & Tests $^{\mathbf{a}}$ \\
\hline & Ifrane (\%) & Sefrou (\%) & \\
\hline Age of farmer (years) & & & $\mathrm{V}=0.348$ \\
Less than 30 & 10.5 & 9.5 & \\
From 30 to 40 & 26.4 & 42.9 & \\
From 41 to 50 & 15.8 & 28.6 & \\
From 51 to 60 & 36.8 & 9.5 & \\
More than 60 & 10.5 & 9.5 & \\
\hline Level of education & & & \\
No education & 31.2 & 42.1 & $\mathrm{~V}=0.139$ \\
Primary school & 37.5 & 26.3 & \\
Secondary school & 18.8 & 21.1 & \\
Tertiary level & 12.5 & 10.5 & \\
\hline
\end{tabular}


Table 2. Cont.

\begin{tabular}{lccc}
\hline Characteristics & \multicolumn{2}{c}{ Province } & Tests $^{\text {a }}$ \\
\hline & Ifrane (\%) & Sefrou (\%) & \\
\hline Apple orchard size (ha) & & & ANOVA * $^{*}$ \\
$\quad$ Less than 5.00 & 37.5 & 90.5 & \\
From 5.00 to 10.00 & 29.2 & 4.8 & \\
From 10.01 to 15.00 & 8.3 & 0.0 & \\
$\quad$ More than 15.00 & 25.0 & 4.8 & \\
\hline Age of an orchard (years) & & & $\mathrm{V}=0.318$ \\
$\quad$ Less than 10 & 55.6 & 25.00 & \\
From 10 to 20 & 22.2 & 40.00 & \\
$\quad$ More than 20 & 22.2 & 35.0 & \\
\hline Orchards covered with anti-hail nets & & & \\
& 75.0 & 25.0 & $\mathrm{~V}=0.435$ * \\
\hline Land tenure & & & $\mathrm{V}=0.137$ \\
$\quad$ Proprietor & 92.0 & 100.0 & \\
$\quad$ Leaseholder & 8.0 & 0.0 & \\
\hline
\end{tabular}

a Tests conducted were one-way ANOVA or Chi-squared with Cramer's V to indicate strength of relation,

* significant at $5 \%$ level.

The data analysis showed that over $90 \%$ of the orchards were less than 5 ha in size in Sefrou province while this segment represented only $37.5 \%$ in Ifrane. A one-way ANOVA test was conducted to compare the effect of the size of apple orchards between provinces. There was a significant effect of the size at the $P<0.05$ level for the two conditions $(\mathrm{F}(1,43)=7.610, P=0.008)$. The result also showed that there were more small-scale farmers in Sefrou and more large-scale farmers in Ifrane.

\subsubsection{Origin of Plant Materials}

All the apple growers interviewed adopted grafting technique of propagation. Up to $70 \%$ of the nursery stocks used were obtained from nursery farms within the country while $30 \%$ were imported from European countries (Figure 2). The plant materials imported were from France and Italy. The source of plant materials utilized by growers in the two provinces was similar.

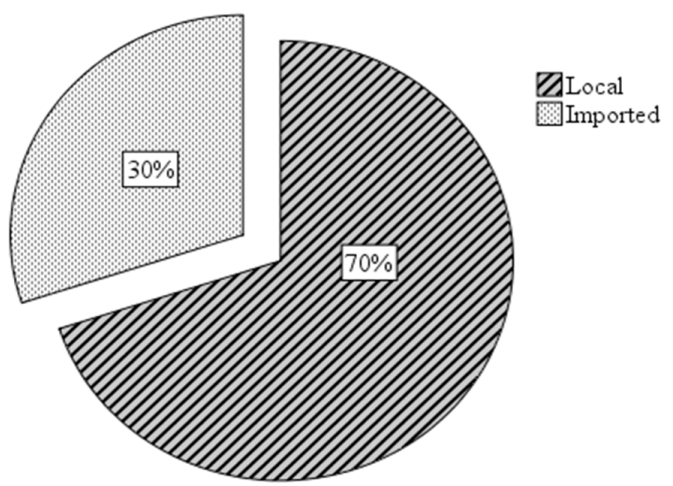

Figure 2. Origin of apple nursery stocks in the provinces of Ifrane and Sefrou.

A range of cultivars are present in the two provinces. Some of these cultivars were chosen because of their chilling requirements and yield rather than resistance to pests and diseases. However, some apple farmers claimed that their cultivars were resistant to at least one disease and susceptible to the others. The cultivar 'Story', a typical cultivar grown by some farmers in the province of Ifrane, was said to be resistant to apple scab and very susceptible to powdery mildew. One of the basic principles of integrated crop and pest management is planting cultivars that are resistant to pests and diseases. Only $10 \%$ of farmers confirmed growing apple scab-resistant cultivars in their orchards. 
Most of the planted cultivars were Golden delicious (87.0\%), Gala (60.9\%), Starking Delicious (26.1\%) and Jéromine $(21.7 \%)$, with a small percentage of Royal Gala, Golden Smith, Story, and others. The rootstocks reportedly available in the surveyed provinces were MM111, M7, M9, M106, M45 and P80.

\subsubsection{Soil and Water Management Practices}

According to the survey conducted, $20.0 \%$ of the farmers had their soil analyzed at least once every two years, $31.1 \%$ every three to five years and $48.9 \%$ never carried out soil analysis. Growers from the two provinces had similar approaches to soil testing (Cramer's V $=0.511, P<0.001$ ).

The sources of irrigation water in the region were wells and rivers. The latter source was often used for surface irrigation. The average depth of water wells ranged from 60 to $80 \mathrm{~m}$. In drip irrigation, the average dose was 1.5 to $4.5 \mathrm{~L} /$ day every 2 days. Considering the types of irrigation, there were more cases of drip irrigation in Ifrane province than in Sefrou, and more cases of surface irrigation in Sefrou compared to Ifrane (Cramer's $V=0.371, P<0.05$ ). In addition, there was a weak association in the case of water analysis before irrigation (Cramer's V $=0.225, P>0.05$ ). Moreover, $67 \%$ of farmers in Ifrane province and 33\% in Sefrou performed water analysis for their orchards.

A multiple response set of three categories on the combined analysis showed that soil and water analyses were performed at least once every two years in $23.1 \%$ of the orchards of Ifrane provinces managed under drip irrigation. In Sefrou province, $13.6 \%$ of the orchards satisfy the aforementioned conditions (Table 3). More than half of the farmers from each province had not carried out these analyses at all during the previous five years.

Table 3. Cross-tabulation of multiple responses on soil and water analyses.

\begin{tabular}{|c|c|c|c|c|c|c|}
\hline \multicolumn{7}{|c|}{ Soil_Water_analysis $\times$ Irrigation_Type $\times$ Province Crosstabulation ${ }^{\text {a }}$} \\
\hline \multirow{2}{*}{\multicolumn{4}{|c|}{ Province }} & \multicolumn{2}{|c|}{ Type of Irrigation } & \multirow{2}{*}{ Total } \\
\hline & & & & Drip Irrigation & Surface Irrigation & \\
\hline \multirow{4}{*}{ Ifrane } & \multirow{3}{*}{$\begin{array}{l}\text { Soil and Water } \\
\text { Analysis }{ }^{b}\end{array}$} & $\begin{array}{l}\text { Once every } \\
2 \text { year }\end{array}$ & $\begin{array}{c}\text { Count } \\
\% \text { wSWA } \\
\% \text { wIT }\end{array}$ & $\begin{array}{c}9 \\
100.0 \% \\
23.1 \%\end{array}$ & $\begin{array}{c}0 \\
0.0 \% \\
0.0 \%\end{array}$ & 9 \\
\hline & & $\begin{array}{l}\text { Once every } \\
3-5 \text { year }\end{array}$ & $\begin{array}{c}\text { Count } \\
\% \text { wSWA } \\
\% \text { wIT }\end{array}$ & $\begin{array}{c}16 \\
100.0 \% \\
41.0 \%\end{array}$ & $\begin{array}{c}0 \\
0.0 \% \\
0.0 \%\end{array}$ & 16 \\
\hline & & Never & $\begin{array}{c}\text { Count } \\
\% \text { wSWA } \\
\% \text { wIT }\end{array}$ & $\begin{array}{c}14 \\
70.0 \% \\
35.9 \%\end{array}$ & $\begin{array}{c}6 \\
30.0 \% \\
100.0 \%\end{array}$ & 20 \\
\hline & & & Count & 39 & 6 & 45 \\
\hline \multirow{4}{*}{ Sefrou } & \multirow{3}{*}{$\begin{array}{l}\text { Soil and Water } \\
\text { Analysis }{ }^{b}\end{array}$} & $\begin{array}{l}\text { Once every } \\
2 \text { year }\end{array}$ & $\begin{array}{c}\text { Count } \\
\% \text { wSWA } \\
\% \text { wIT }\end{array}$ & $\begin{array}{c}3 \\
100.0 \% \\
13.6 \%\end{array}$ & $\begin{array}{c}0 \\
0.0 \% \\
0.0 \%\end{array}$ & 3 \\
\hline & & $\begin{array}{c}\text { Once } \\
\text { every 3-5 year }\end{array}$ & $\begin{array}{c}\text { Count } \\
\% \text { wSWA } \\
\% \text { wIT }\end{array}$ & $\begin{array}{c}4 \\
80.0 \% \\
18.2 \% \\
\end{array}$ & $\begin{array}{c}1 \\
20.0 \% \\
5.6 \% \\
\end{array}$ & 5 \\
\hline & & Never & $\begin{array}{c}\text { Count } \\
\% \text { wSWA } \\
\% \text { wIT }\end{array}$ & $\begin{array}{c}15 \\
46.9 \% \\
68.2 \% \\
\end{array}$ & $\begin{array}{c}17 \\
53.1 \% \\
94.4 \%\end{array}$ & 32 \\
\hline & \multicolumn{2}{|c|}{ Total } & Count & 22 & 18 & 40 \\
\hline
\end{tabular}

Percentages and totals are based on responses. wSWA: within Soil-Water-Analysis, wIT: within Irrigation-Type.

a There are not enough (less than 2) multiple response groups for pairing. Percentages are based on responses, but no pairing is performed. ${ }^{b}$ Paired group (Soil and Water Analysis).

\subsubsection{Thinning}

According to the survey, $84 \%$ of the respondents thinned their fruits manually and only $2 \%$ used chemical thinning with carbaryl (Figure 3). There was a strong association between the two provinces 
(Cramer's $\mathrm{V}=0.401, P<0.05)$. This activity is performed from May to June in the region depending on the type of cultivar.

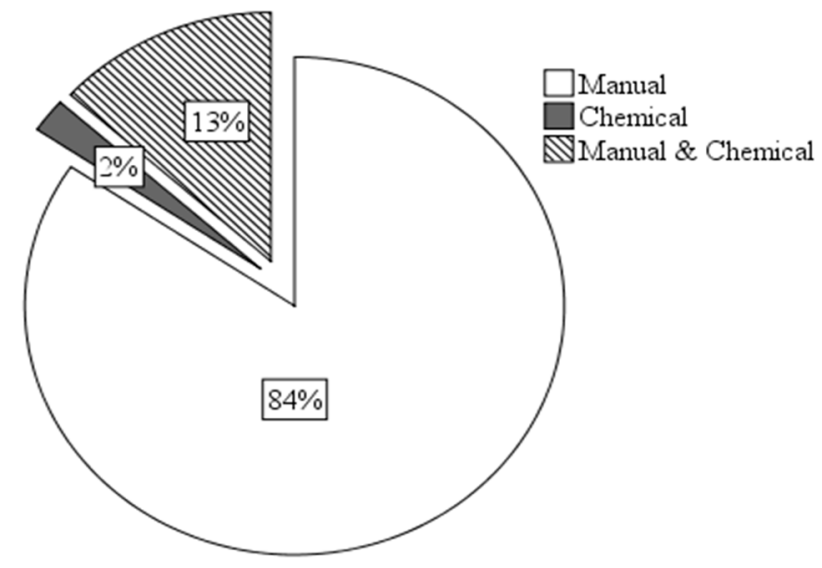

Figure 3. Types of thinning involved in apple production in the region of Fes-Meknes.

According to face-to-face discussion with farmers, chemical thinning has some disadvantages in that it requires a great deal of knowledge about the products to be used. It most often results in loss of yield and as such the consequences to productivity are detrimental.

\subsubsection{Yield}

High yield is of paramount importance and is the ambition of every farmer. From the survey in the two provinces, the average yield for the past five years varied from 16 to $40 \mathrm{t} / \mathrm{ha}$. This highlights the fluctuation in productivity across the provinces. The average yields of the provinces of Ifrane and Sefrou were about 30 and $25 \mathrm{t} / \mathrm{ha}$, respectively, in 2017. However, there was no significant difference between the surface area of the orchard and the yield.

Generally, farmers use pesticide application to control pests and diseases with the aim of obtaining higher yields. To check whether similar conclusions could be made for apple farmers, we conducted a multiple regression analysis. The model $\left(R^{2}=0.003, P>0.05\right)$ based on age of apple trees (standardized regression coefficient $\mathrm{B}=-0.028, P>0.05)$ and pesticide application $(\mathrm{B}=0.041, P>0.05)$ could explain the important variation observed, as reported by farmers (Table 4). Yield did not seem to be influenced by either age of apple trees or the amount of pesticides applied or both.

Table 4. Regression of apple yield on age of apple trees and number of pesticide application.

\begin{tabular}{|c|c|c|c|c|c|c|c|c|c|c|}
\hline \multirow{3}{*}{ Model } & \multicolumn{9}{|c|}{ Coefficients $^{\mathrm{a}}$} & \\
\hline & & & & \multirow{2}{*}{$t$} & \multirow{2}{*}{ Sig. } & \multicolumn{2}{|c|}{$95.0 \%$ Confidence Interval for B } & \multicolumn{3}{|c|}{ Correlations } \\
\hline & B & Std. Error & Beta & & & Lower Bound & Upper Bound & Zero-Order & Partial & Part \\
\hline $\mathrm{AAO}$ & -0.028 & 0.102 & -0.042 & -0.275 & 0.785 & -0.234 & 0.178 & -0.039 & -0.042 & -0.042 \\
\hline NPP & 0.041 & 0.168 & 0.038 & 0.246 & 0.807 & -0.297 & 0.379 & 0.034 & 0.037 & 0.037 \\
\hline
\end{tabular}

${ }^{a}$ A-Dependent Variable: Yield in t/ha, t: $t$-test. AAO-Age of an apple orchard, NPP-Number of pesticide application per annum, B-Unstandardized Coefficients, Beta-Standardized Coefficients.

\subsection{Farmers' Knowledge and Perceptions in Pest Management}

In response to the question concerning the major diseases in their orchards, farmers on average mentioned $1.87(\mathrm{SD}=0.86)$ different pathogens in the course of the survey (Table 5). The presence of the diseases in the orchards was recognized by the symptoms and the physiological stages of apple trees. Estimated yield losses from diseases were generally not known by farmers although all of the farmers reported that there was a greater cost from purchasing insecticides and acaricides than fungicides. Independently, the most frequently reported diseases were apple scab caused by Venturia 
inaequalis (Cooke) G. Wint. (82.6\% of farmers) and apple powdery mildew, caused by Podosphaera leucotricha ((Ell. and Evherh.) E.S. Salmon)) (73.9\%). Other diseases of great economic importance were Phytophthora spp. and fire blight of apple (Erwinia amylovora) according to $21.7 \%$ and $8.7 \%$ of the farmers, respectively.

Table 5. Wilcoxon's test for comparing farmer's perceptions of pests and diseases in an orchard.

\begin{tabular}{ccccccc}
\hline & \multicolumn{2}{c}{ Insect Pests } & \multicolumn{2}{c}{ Diseases } & Z & Sig \\
\hline \multirow{2}{*}{ Perceptions } & Mean & SD & Mean & SD & & \\
& 2.69 & 0.98 & 1.87 & 0.86 & -3 & $0.0056^{* *}$ \\
\hline \multicolumn{6}{c}{ SD: standard deviation. ${ }^{* *}$ Significant at $P$} & $<0.01$ \\
\end{tabular}

SD: standard deviation. ${ }^{* *}$ Significant at $P<0.01$.

With regard to insect pests, farmers on average observed $2.69(\mathrm{SD}=0.98)$ different insect pests and all farmers mentioned insects from five specific families: Tortricidae, Aphididae, Diaspididae, Tetranychidae and Psyllidae. Of the farmers interviewed, 63\% reported tortrids, notably codling moth, Cydia pomonella L. (Lepidoptera: Tortricidae), for causing production losses. Up to 67\% mentioned infestations of tetranychid mites, Panonychus ulmi Koch and Tetranychus urticae Koch (Acari: Tetranychidae). About 78\% reported aphids, which comprised mainly three species: woolly aphid, Eriosoma lanigerum Hausmann; green apple aphid, Aphis pomi De Geer; and rosy apple aphid, Dysaphis plantaginea Passerini (Hemiptera: Aphididae). Scale insects were mentioned by $30 \%$ of respondents; a well-known species was San Jose scale, Quadraspidiotus perniciosus Comstock (Hemiptera: Diaspididae). Only a few farmers mentioned infestations of psyllids.

\subsection{Pest Management Practices}

In apple farming, farmers' decision-making on pesticide use does not seem to be based on economic rationale. These decisions, often doubtful, are influenced more by perceptions of the pests and expected benefits from spraying.

\subsubsection{Pruning and Dormant Sprays}

All the respondents performed dormant and green pruning in the course of production. All farmers interviewed use shears to trim unwanted branches. It is important that this practice is done to avoid the transfer of diseases from one tree to another. Farmers used a range of disinfectants after every pruning and reported disinfecting pruning tools with sodium hypochlorite and covering cut wounds with mastic gum or copper compounds, especially copper sulfate.

About $50 \%$ of the farmers burned their pruned twigs, $23 \%$ of them gave them to farm laborers or used them for fencing around the orchard, while the rest were milled and reused as mulch for the orchard floor.

\subsubsection{Disease Management}

Losses due to diseases have not been estimated in the region. According to respondents, application of pesticides was usually performed when visible symptoms appeared or during a particular physiological stage as a preventive measure depending on environmental conditions.

Farmers reported the use of the same active ingredients to control both apple scab and apple powdery mildew. A total of nine systemic fungicides belonging to the classes of benzimidazoles (thiophanate-methyl and carbendazim), strobilurins (trifloxystrobin and kresoxim-methyl) and triazoles (difenoconazole, myclobutanil, propiconazole, hexaconazole and tetraconazole) were recorded. The most used systemic active ingredient was thiophanate-methyl (9.7\%) (Figure 4). However, contact fungicides were used more often than systemic fungicides. Sulphur compounds were the most used (15.2\%). In addition to dormant sprays, an average of seven to eight treatments per year was reported. 


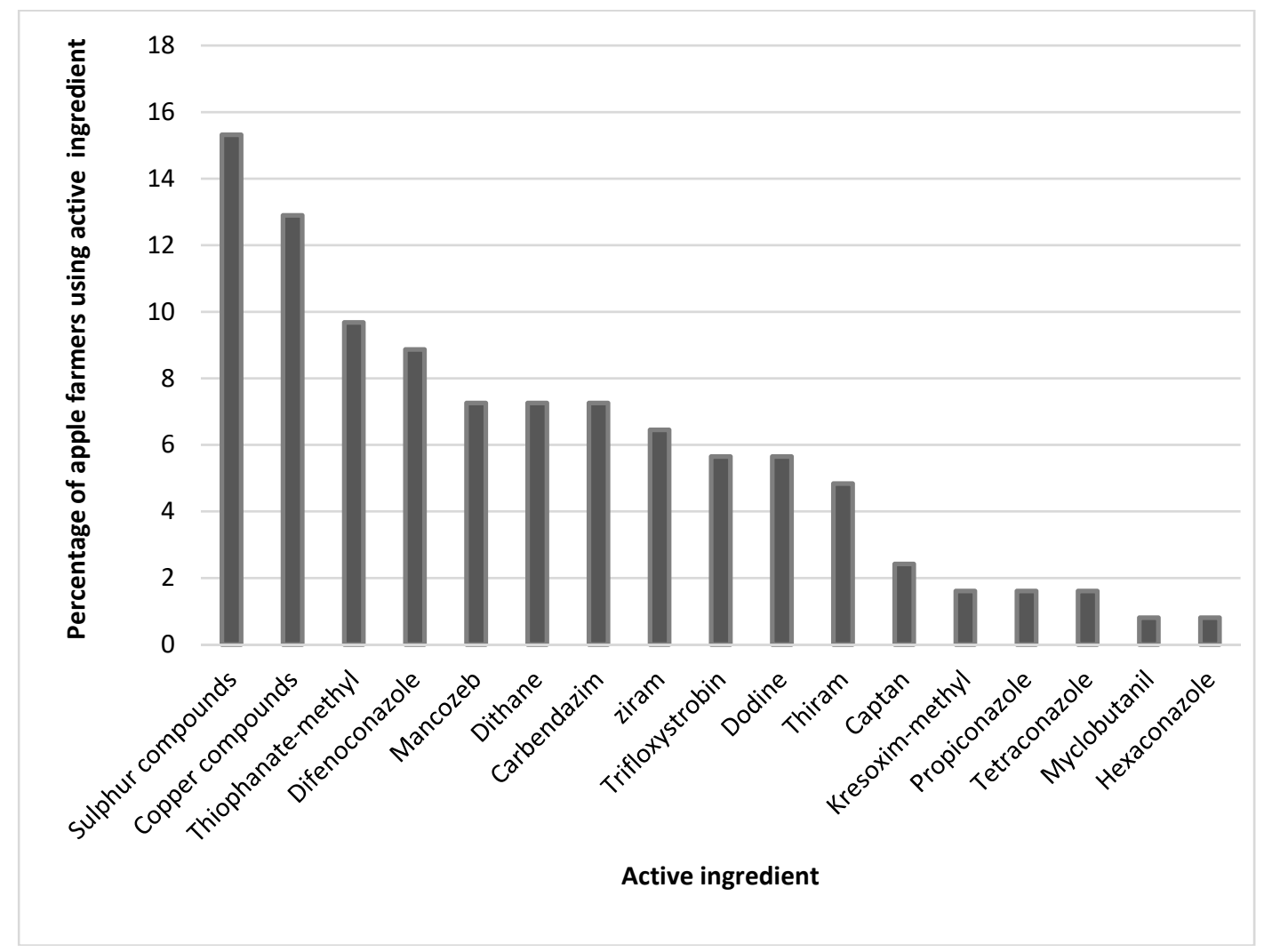

Figure 4. Management of apple scab and powdery mildew with pesticides.

Compared to apple scab and powdery mildew, there were fewer products mentioned and fewer cases of fire blight caused by E. amylovora. Active ingredients like fosetyl-aluminum, plant growth regulators, and REGALIS (Prohexadione-calcium) were reported by about $30 \%$ of farmers. The farmers reported they used a combination of sanitation, cultural practices, and dormant sprays to keep the disease in check. All farmers that reported root rot disease caused by Phytophthora spp. used fosetylaluminum as the sole active ingredient.

\subsubsection{Insect Pest Management}

Farmers reported four major families of insect pests and the systemic products they used to control them were recorded (Table 6). A total of 42 registered insecticide products were used, corresponding to 13 active ingredients and 17 acaricide products grouped into three modes of action. Each respondent used these active ingredients at an average of $5.81(\mathrm{SE}=0.66)$. There was confusion over the names of active ingredients, implying that each active ingredient may be repeatedly used due to having different commercial names. For instance, a farmer could be asked if they carried out rotation of active ingredients. They may claim that they rotated active ingredients based on the fact that they changed trade names, when in reality they have not rotated active ingredients at all. As an example, imidacloprid was used under four different trade names, viz, Confidore, Nupride, Pride and Imiducel.

The highest number of different products from a chemical class of insecticides were the synthetic pyrethroid products (five active ingredients), followed by the organophosphates (four active ingredients). Imidacloprid was the most-used active ingredient reported by respondents. Six active ingredients were used to control both codling moths and aphids. There were also several active ingredients applied against spider mites. For the scales, dormant sprays were most often mentioned by farmers, which call for little demand for systemic products. One-sample binomial with the test proportion of 0.5 showed that there were significant differences according to response percentages of each active ingredient (Table 6). 
Table 6. Insecticide and acaricides used to control apple pests in Fes-Meknes region.

\begin{tabular}{|c|c|c|c|c|c|c|c|}
\hline \multirow{2}{*}{$\begin{array}{l}\text { Chemical Class/Active } \\
\text { Ingredient }\end{array}$} & \multicolumn{4}{|c|}{ Used to Control Insect Pests $\left(1^{a}, 0^{b}\right)$} & \multirow{2}{*}{ Total No. } & \multirow{2}{*}{$\begin{array}{l}\text { Response } \\
\text { Percentages }\end{array}$} & \multirow{2}{*}{ Test ${ }^{c}$} \\
\hline & $\mathrm{CM}$ & Ap & SM & SI & & & \\
\hline \multicolumn{8}{|l|}{ Carbamates } \\
\hline Methomyl & 1 & 1 & 0 & 0 & 17 & 7.0 & 0.105 \\
\hline Pirimicarb * & 0 & 1 & 0 & 0 & 8 & 3.3 & 0.000 \\
\hline \multicolumn{8}{|l|}{ Organophosphates } \\
\hline Chlorpyrifos-ethyl & 1 & 0 & 0 & 1 & 18 & 7.4 & 0.185 \\
\hline Dimethoate & 0 & 1 & 0 & 0 & 16 & 6.6 & 0.055 \\
\hline Malathion & 1 & 1 & 0 & 0 & 17 & 7.0 & 0.105 \\
\hline Methidathion * & 1 & 0 & 0 & 1 & 11 & 4.5 & 0.001 \\
\hline \multicolumn{8}{|l|}{ Synthetic pyrethroids } \\
\hline Alpha-cypermethrin * & 1 & 1 & 0 & 0 & 13 & 5.3 & 0.010 \\
\hline Bifenthrin * & 1 & 0 & 1 & 0 & 14 & 5.8 & 0.012 \\
\hline Cypermethrin * & 1 & 0 & 0 & 0 & 12 & 4.9 & 0.002 \\
\hline Deltamethrin & 1 & 1 & 0 & 0 & 16 & 6.6 & 0.055 \\
\hline Lamda-cyhalothrin & 1 & 1 & 0 & 0 & 16 & 6.6 & 0.055 \\
\hline \multicolumn{8}{|l|}{ Chloronicotinyl } \\
\hline Imidacloprid & 0 & 1 & 0 & 0 & 19 & 7.8 & 0.302 \\
\hline Thiacloprid & 1 & 1 & 0 & 0 & 16 & 6.6 & 0.055 \\
\hline \multicolumn{8}{|l|}{ Neonicotinoid } \\
\hline Thiamethoxam * & 0 & 1 & 0 & 0 & 5 & 1.6 & 0.000 \\
\hline \multicolumn{8}{|l|}{ Avermectin } \\
\hline Abamectin & 0 & 0 & 1 & 0 & 16 & 6.6 & 0.055 \\
\hline \multicolumn{8}{|l|}{ Sulfites } \\
\hline Propargite & 0 & 0 & 1 & 0 & 18 & 7.4 & 0.185 \\
\hline
\end{tabular}

$1^{\mathrm{a}}$ : Active ingredient used to control the insect pest by an apple farmer. $0^{\mathrm{b}}$ : Active ingredient reported was not used against the mentioned pest even though it is used by the same farmer against other target pests. ${ }^{c}$ One-sample binomial test. Asymptotic significances are displayed. ${ }^{*}$ Significant at $5 \%$ level. $\mathrm{CM}=$ Codling moth, Ap $=\mathrm{Aphids,}$ $\mathrm{SM}=$ Spider mites and $\mathrm{SI}=$ Scale insects .

\subsubsection{Weed Control}

Weed control methods adopted by these farmers were diverse. Among the farmers interviewed, $31.8 \%$ weeded their orchard manually, followed by mechanical weed control $(22.7 \%)$ and chemical weed control (15.9\%). There were an equal proportion of farmers who combined manual and mechanical weeding and mechanical and chemical weeding (Figure 5). Larger farms were found to have adopted mechanical and chemical weeding whereas smaller ones whose surface area is less than 1.5 ha preferred manual weed control methods (Cramer's V $=0.416, P>0.05$ ). There were some farmers whose orchards were grazed by cattle, but the grazing animals had to be monitored so that they did not damage apple trees. This animal grazing practice was observed among small-scale farmers.

Those who practiced chemical weeding had access to limited active ingredients and rotation of ingredients was rare. The herbicides used in the provinces surveyed were NASA 36SL (glyphosate) and AFFINEX ( $5 \mathrm{~g} / \mathrm{L}$ Carfentrazone-ethyl $+360 \mathrm{~g} / \mathrm{L}$ glyphosate isopropylamine salt).

\subsection{Pesticide Use}

Surveillance is an important preliminary step in pest management. It allows farmers to determine what pests are present and their numbers and make an informed decision on whether spraying is economically justified to prevent crop damage. About $60 \%$ of the respondents surveyed their orchards by observation to diagnose damage before spraying pesticides. These farmers moved within the orchards and carried out visual inspection. It served not only to control pests and diseases but also to assess the damage caused by adverse weather conditions during spring. A one-way Chi-squared test (Table 7) showed a significant difference between the adopters and non-adopters $\left(\chi^{2}=7.714, P<0.05\right)$. There was an equal case between the two provinces of those who monitored and those who did not. 
Unfortunately, regular inspection and monitoring of these farms were carried out without considering action thresholds before pesticide application.

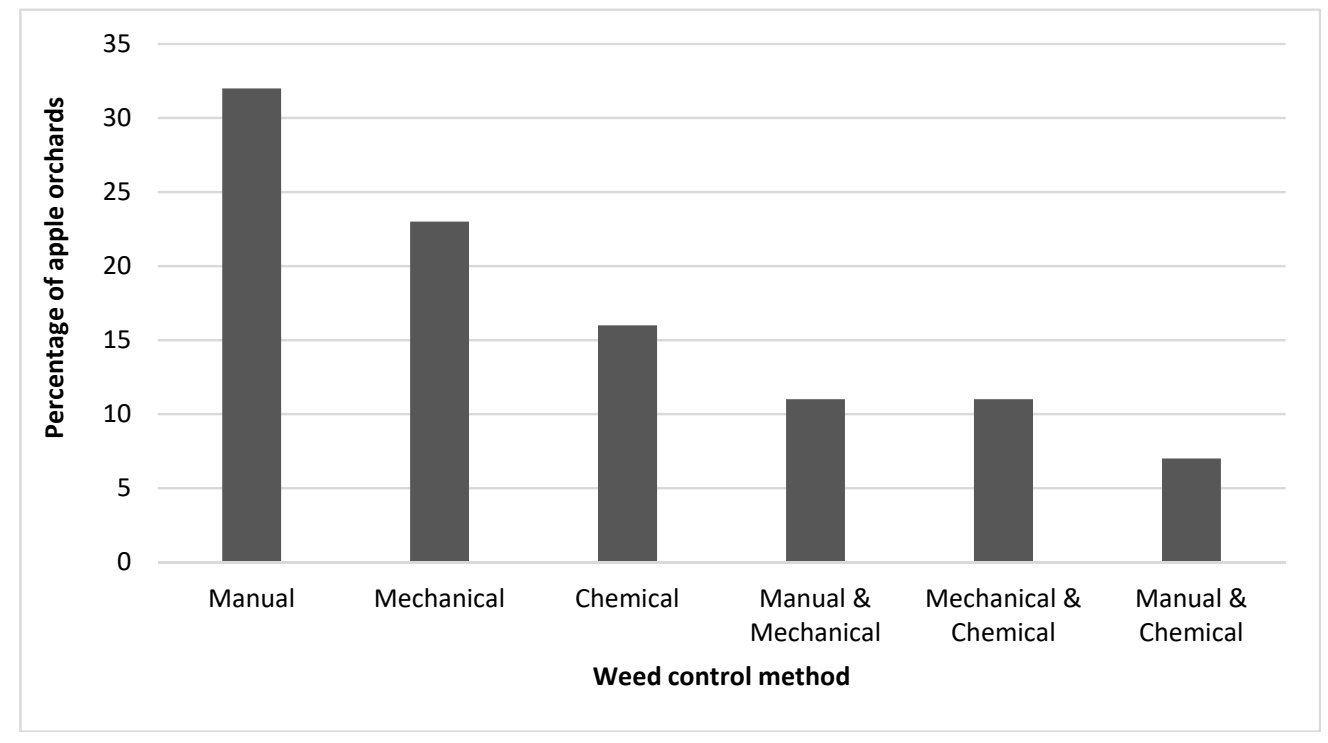

Figure 5. Categories of weed control methods practiced by apple farmers.

Table 7. Cross-tabulations and one-sample Chi-squared tests showing the apple farmers' pesticide use practices.

\begin{tabular}{|c|c|c|c|c|}
\hline \multirow{2}{*}{ Famers' Responses } & \multirow{2}{*}{$\begin{array}{l}\text { Observed } \\
\text { Frequency }\end{array}$} & \multicolumn{3}{|c|}{ Statistical Values } \\
\hline & & df & Pearson $\chi^{2}$ & $P$-Value \\
\hline Surveillance of pests and diseases * & & 1 & 7.714 & 0.005479 \\
\hline Yes & 30 & & & \\
\hline No & 12 & & & \\
\hline Calendar-based treatments & & 1 & 0.257 & 0.612090 \\
\hline Yes & 16 & & & \\
\hline No & 19 & & & \\
\hline Do you alternate your phytosanitary products? $* *$ & & 1 & 21.125 & 0.000004 \\
\hline Yes & 39 & & & \\
\hline No & 3 & & & \\
\hline Compliance with pre-harvest interval ** & & 1 & 14.235 & 0.000161 \\
\hline Yes & 28 & & & \\
\hline No & 6 & & & \\
\hline Postharvest treatments with fungicides & & 1 & 2.133 & 0.144000 \\
\hline Yes & 19 & & & \\
\hline No & 11 & & & \\
\hline
\end{tabular}

${ }^{*}$ significant $P$-values at the $5 \%$ level, ${ }^{* *}$ significant $P$-values at the $0.1 \%$ level.

The choice of phytosanitary products is of paramount importance in plant and environmental protection (Figure 6). To understand the major influences on farmers' decision-making, they were asked on what basis they chose their pesticides. Pesticide sellers were relied upon by $41.9 \%$ of the surveyed farmers. More importantly, farmers in Sefrou province (62\%) relied more on pesticide sellers than those in Ifrane (23\%). The difference between the two provinces was significant (Cramer's $\mathrm{V}=0.606, P<0.05)$.

A large amount of pesticides could be applied in apple orchards if cultural and sanitation practices are well implemented. A number of farmers reported applying pesticides 8 to 40 times in the course of a growing season and the average number of treatments of all correspondents was 20 . In addition to the application of dormant sprays, 7 to 8 treatments were applied to control apple scab, 8 to 10 for codling moth and 3 to 4 for mites on average. 


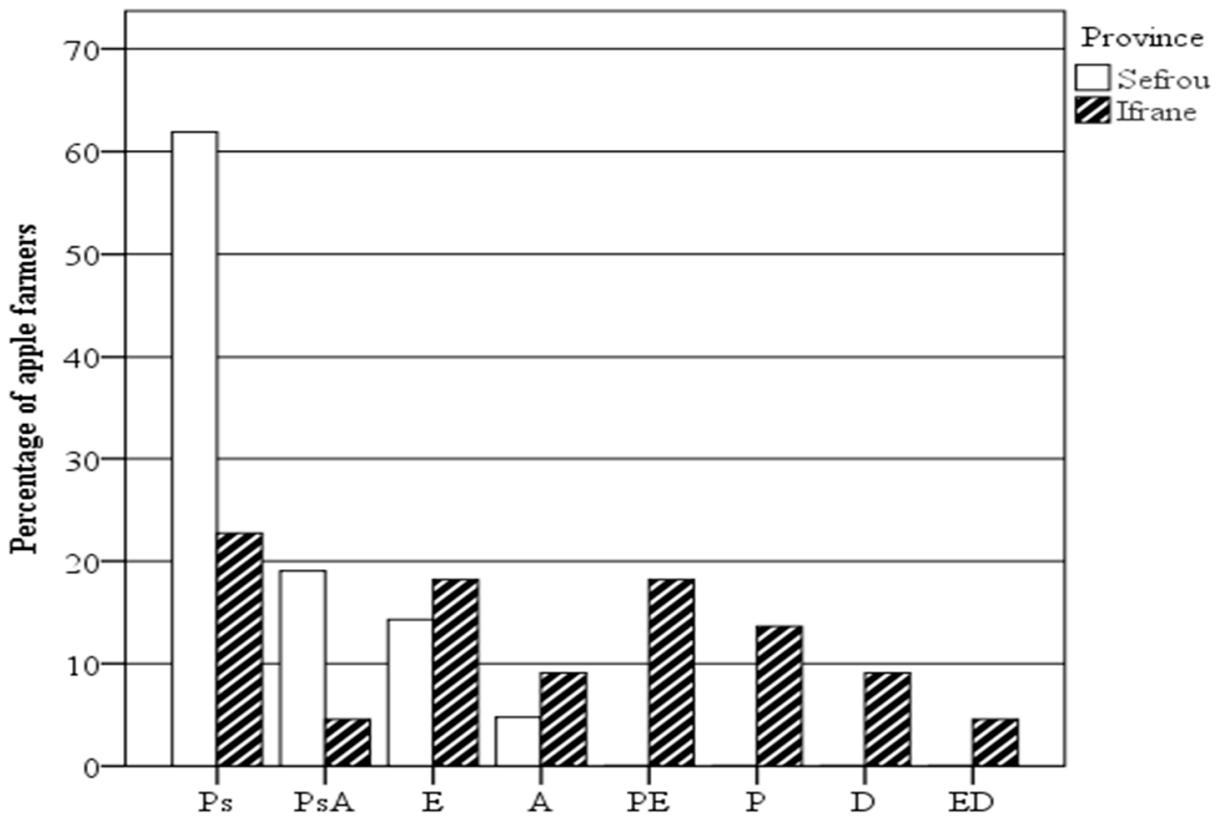

Figure 6. Provincial differences in choice of phytosanitary products. Ps $=$ Pesticide seller, PsA = Pesticide seller and Advisor, $\mathrm{E}=$ Efficacy, $\mathrm{A}=$ Advisor, $\mathrm{PE}=$ Price and Efficacy, $\mathrm{P}=$ Price, $\mathrm{D}=$ Diagnostic, ED = Diagnostic and Efficacy.

Calendar-based treatments are economically important to manage pests and diseases in an orchard. About $60 \%$ of the farmers in Ifrane province established treatments based on calendar compared with $35 \%$ in Sefrou. With regard to efficacy of pesticides, the apple farmers assessed the orchards a few days after treatment depending on the persistence of the products. They would then observe if there were occurrences of pests and diseases or their symptoms.

A pre-harvest interval is maintained in order to assure consumers of the relative safety of fruits from pesticide residues. Almost all the farmers were aware of this safety measure and they explained that it should be reinforced. Seventy-six percent of farmers from each province complied with the pre-harvest interval to ensure that there were no pesticide residues on their fruits.

The alternation of active ingredients with different modes of actions helps avoid resistance. Of the farmers surveyed, $90.6 \%$ affirmed rotating active ingredients and were aware of the phenomenon of resistance whilst $9.4 \%$ were ignorant of this fact.

Up to $63 \%$ of farmers performed postharvest treatments even though there was little association between the adopters and non-adopters. These farmers used both contact and systemic fungicides and disinfectants. The main systemic fungicides used were thiophanate-methyl, difenoconazole and carbendazim.

\subsection{Farmers' Perceptions on Climate Change}

When apple farmers were interviewed about the major issues they face, they mentioned adverse weather conditions, namely frosts, hailstorms, hot winds and water shortage. During the survey, only a few farmers reported water shortages and hot winds although they pose serious issues. There is a perception that temperature and rainfall patterns have undergone a significant shift, and that rainfall overall has recently increased. However, farmers were not dependent on rainfall as a source of water for the apple orchards. Previous periods with low temperatures during the winter season (useful for the induction of dormancy, bud break and ensuring flowering in apple trees) were no longer observed. In fact, temperatures at times remained above normal during the winter season. According to farmers, late snowfall in February and March resulted in lower temperatures and thereby a late onset of spring.

According to face-to face discussions, farmers believe that apple trees require a chilling period for proper physiological development. All respondents made similar claims that chilling requirements 
were not being met with mild winters. They added that a chilling period would disrupt the life cycle of pests and diseases. Hailstorms can also destroy apple trees and possibly the entire orchard. The fruit is the most vulnerable organ that is affected by hail. As a result, fruit quality is compromised by physical injury and reduced leaf area. In addition, the risk of pathogen penetration via injury is greater. Frost can cause total destruction of flowers and fruits. When the duration of frost is short, a gel-like ring will appear on the young apple fruit. Frost occurs in dry weather, clear nights and very light winds. Water shortage leads to drought that can have negative consequences for production. Because of these possibly damaging events, more than $65 \%$ of apple farmers from each province check the local weather forecast daily (Figure 7).

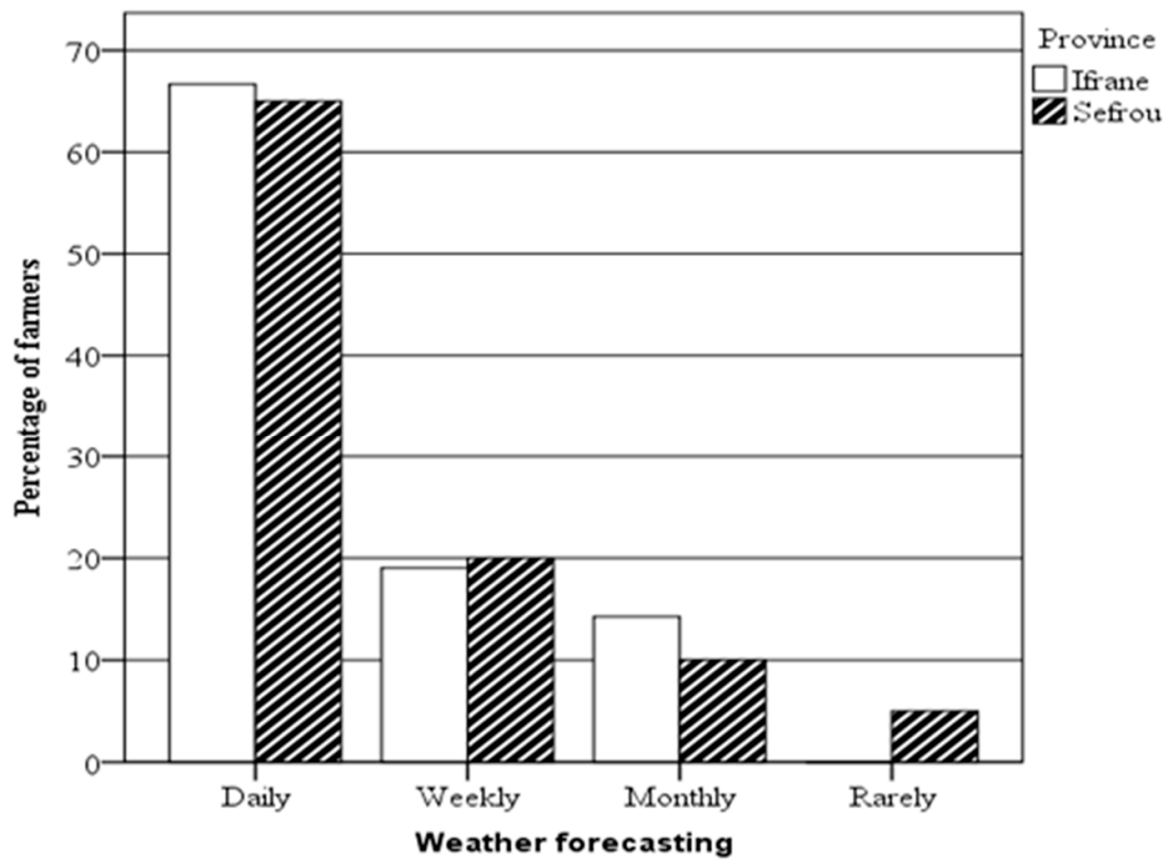

Figure 7. Local weather forecasting by apple farmers.

Among the farmers interviewed, 51.3\% used anti-hail nets in their orchards (Figure 8). Seventy-five percent of the respondents in Ifrane province had their orchards covered with nets compared with only $25 \%$ in Sefrou province (Table 2). There was a significant difference between the two provinces with respect to the percentage of orchards covered with anti-hail nets (Cramer's V = $0.435, P<0.05)$.
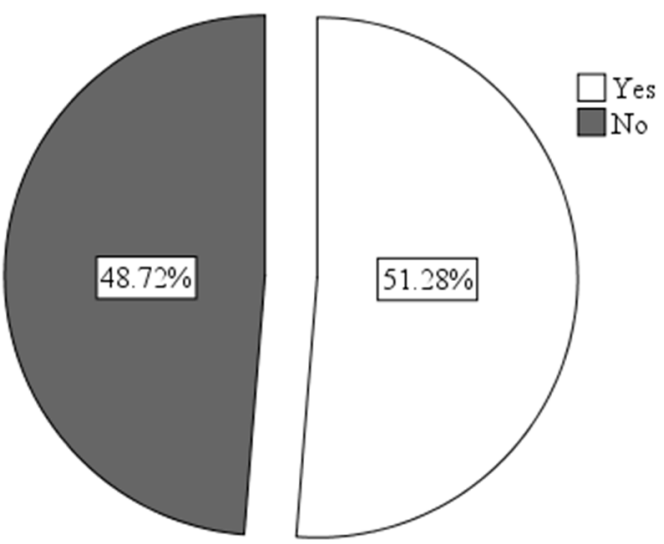

Figure 8. Availability of apple orchards with anti-hail nets in the two provinces. 


\subsection{Farmers' Awareness of Organic Apple Production}

During the survey, all farmers stated they used a combination of cultural and chemical control methods, however there was no use of biological methods by any of the participants.

According to the information obtained from the survey in the two provinces, none of the farmers interviewed had been formally trained in biological pest management or even organic apple production. Some farmers had heard about using natural enemies to control pests and pathogens but they said they did not know how to make use of them properly. Furthermore, there was no report of any farmer having an organic orchard in either of the two provinces surveyed. In fact, some farmers (about $60 \%$ ) admitted to not having any knowledge about biological control methods. There was a statistical difference between the farmers who were aware of organic apple farming between the two provinces (Cramer's $\mathrm{V}=0.314, P<0.05)$. Nonetheless, $40.5 \%$ of farmers stated they were willing to convert to organic farming in the future (Figure 9). This depends on the market conditions for organic produce in the region and whether they can receive adequate training. Other farmers interviewed, however, felt that switching to an organic system would be difficult due to the amount of new knowledge they would need to accrue, such as regarding the proper implementation of biological controls.

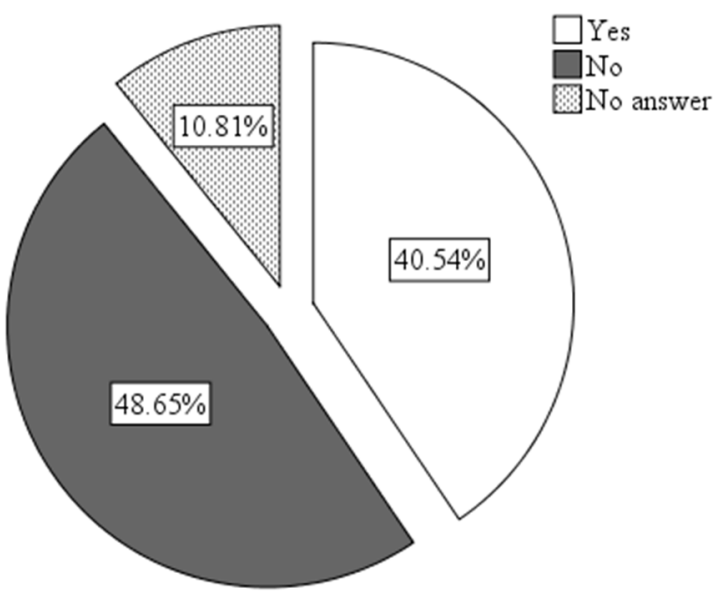

Figure 9. Apple farmer's response to conversion to organic apple production.

\section{Discussion}

The present study shows that the high fluctuations in productivity of apple growing in the Fes-Meknes region of Morocco are due to the poor practices, low knowledge, and perceptions of apple farmers as well as adverse weather conditions. The data were collected from apple farmers in specific areas of the region as orchards tend to be clumped together in places where land is amenable to apple production. Perceiving pests is not enough for farmers. Their existing practice and knowledge with regard to understanding pests' life cycle, and appropriate time and method of pesticide use were, to some extent, low. The farmers hardly used biological control methods. Similar findings have been reported by [13]. Farmers with small orchards (area less than five hectares) have most often lower yields than farmers with large orchards [6]. This could be due to the adoption of very good agronomic practices including pest management.

The major insect pests reported by apple farmers in the provinces of Ifrane and Sefrou have been described independently as the major pests to apple production in the region of Fes-Meknes [14-17]. According to [18], the pest damage caused to apple trees in Morocco is mainly due to codling moth (C. pomonella), aphids (A. pomi, E. lanigerum and D. plantaginea), mites (P. ulmi and T. urticae), and San Jose scale (Q. perniciosus). Aphids, codling moth and spider mites were mentioned by more than $60 \%$ of the respondents while $30 \%$ of them reported scale insects in their orchards. These insects have been described worldwide as major insect pests to apple production [19]. According to [20], codling moth can develop in orchards in mountainous regions $1800 \mathrm{~m}$ above sea level in Morocco. 
According to [21], the major diseases of apples in Morocco are apple scab (V. inaequalis), apple powdery mildew (P. leucotricha), fire blight in apples (E. amylovora), apple root rots (Phytophthora spp.) and brown rot (Monilinia spp.). These diseases affect apple trees worldwide [7]. In the course of our survey, farmers were able to describe the symptoms of the diseases more or less depending on the plant organs affected and the apple growth stage. Although other diseases may result in yield losses during an outbreak year, $82.6 \%$ and $73.9 \%$ of farmers mentioned apple scab and powdery mildew, respectively, as major disease issues in their orchards. Indeed, $V$. inaequalis is one of the most important diseases of apples worldwide [22]. Farmers were more familiar with the diseases affecting their orchards than the insect pests, but were aware of their presence. This confusion might be due to the numerous species of insect pests that inhabit apple orchards.

Climate change is a global concern and apple farmers have already felt the effects due to an increase in adverse weather conditions such as hailstorms, frosts, water shortage and hot winds. Maazouz [9] emphasizes that climate change is one of the major constraints to the development of the apple sector in Morocco. According to some authors [23], hailstorm damage will increase in the future if global warming leads to further temperature increases in the region. It is estimated that by 2050, climate change may lead to a $25-50 \%$ increase in crop damage due to hailstorms [23]. Apple trees are a temperate zone species, requiring a long period of vegetative dormancy induced by chilling in the order of 800 to $1600 \mathrm{~h}$ of temperatures lower than $7.2^{\circ} \mathrm{C}$. Normally, if the dormancy breaking goes well, flowering will be relatively grouped [24]. Lack of chilling, late snowfall and a quick rise in temperature in February have become common factors leading to a reduction in the period of pollination, which, in turn, hinders fruit setting. Rainfall is another major climatic factor influencing apple productivity as it controls the soil moisture regime and relative humidity. Every respondent in the two provinces reported an increase in the unpredictable pattern of rainfall with the majority occurring very late in the season compared to previous years. They also noted that rainfall was unevenly distributed. This makes apple farmers more dependent on irrigation (Table 3). The amount of water needed by the apple tree for growth and production varies from 700 to $900 \mathrm{~mm} /$ year. The water requirements of the apple tree during the growing season (March to September) would be $600 \mathrm{~mm}$. The strongest demand occurs in July-August [25].

Adaptation measures that entail mitigation of damage may increase the resilience of farmers to the impacts of natural disasters and limit future costs of climate change [23]. Anti-hail nets were used by some farmers in the two provinces. The nets also have an effect on the orchard light microclimate, apple tree growth, fruiting and fruit quality [26]. Even so, in some years and under certain conditions, the nets are necessary [27]. Installation of anti-hail nets is very costly, and is a long-term investment. A significant portion of farmers believed that climate change is occurring and also forecast increased crop losses in the future. Over $65 \%$ of farmers from the two provinces checked local weather forecasts on a daily basis, which will also help them with pest management. Other farmers' adaptation strategies, such as shifts towards new varieties (low chill and high yield varieties), change of crops, irrigation methods and rain water harvesting, use of compost, etc., have been reported by many authors [28-31].

The farmers' KPP in sanitation practices would help support pest and disease management in an orchard. All farmers reported pruning their orchards and the application of dormant sprays. Even though the purpose of pruning is to lighten the branches, ensure sufficient light penetration and establish an annual balance between vegetation and fruiting [25], it is also a sanitation practice which will help prevent pests and diseases. Strong pruning decreases pests and diseases on susceptible and moderately susceptible cultivars compared with unpruned ones [32]. Furthermore, the process will also help to detect and identify the possible presence of diseases or pests [17]. Continuing with prophylactic measures, all the debris and weeds should be removed from old trees to prevent hibernating larva using it as shelter. It is also necessary to band the trees with grass ropes or sackcloth made from jute [33].

The actions of pesticide sellers and authorities involved in plant protection play an important role in providing information and guidance on pesticide selection to farmers and in improving their 
awareness and behavior. Farmers' perceptions about environmental issues could be evaluated on the basis of their priorities in purchasing specific pesticides, and $41.9 \%$ of the respondents relied on recommendations from pesticide sellers (Figure 6). In addition to the application of dormant sprays, an average of 7 to 8 treatments for apple scab, 8 to 10 for codling moth and 3 to 4 for mites were recorded from the respondents. In some cases, the pesticide seller is the only entity who can provide information to farmers who lack information and have low educational levels [34,35]. The trust of farmers depends mainly on the information they receive and the extent to which they believe the providers of the information.

A wide range of pesticides were reported to control diseases and insect pests in an orchard. In order to avoid a high number of pesticide treatments with the same mode of action, it is the duty of farmers to familiarize themselves with the names of active ingredients instead of commercial names $[34,35]$. Although promoting precise knowledge and awareness about pesticide hazards is imperative for encouraging farmers to consider the safety measures that best fit their farm practices and financial affordability when working with pesticides, lack of knowledge is only one of many individual factors that influence decision-making about pesticide use [36,37]. It was reported that chemical sprays were used intensively to control codling moth, with application occurring every 9 to 13 days [20]. The rotation of pesticides with different modes of action during the life cycle of the insect will help prevent resistance from occurring. Spider mites on apple trees require a high number of phytosanitary interventions. Apart from dormant sprays, the number of acaricide treatments can reach four or five a season [16]. An average number of three treatments was recorded during this survey. The choice of the product is related to the pests' population structure. Spider mite populations, for example, have developed resistance to acaricide application and the chemical control no longer seems to be an efficient or a sustainable approach [14-17]. For scale insects, dormant sprays are applied during late dormant stage (before green tip stage) in order to ensure the suppression of the their activities in an orchard [38,39].

Insect monitoring in apple orchards is fundamental in pest management. Sixty percent of respondents monitored pests through visual inspection. For codling moth, pheromone traps help monitor the movements of the moth population. Sexual confusion is part of the integrated control techniques practiced against pests. To do this, diffusers placed in various places in the culture emit a substance (pheromones), which disturbs the recognition of the females by the males, thus disturbing their mating [40]. For heteroecic aphids such as green apple and rosy aphid, the use of yellow sticky traps at flowering stage will help evaluate the level of infestation [15]. These traps have the advantage of providing information on the flight activity of aphids.

Adoption of action thresholds was only reported on codling moth. Action thresholds are important in pest management and have been indicated by different researchers in the region of Fes-Meknes [14-17]. They can be carried out by visual inspection of plant organs in a sampling form and differs from one insect pest to the other. This requires knowledge in the identification of the pests or the damage they cause to the plant organ. For control of codling moth in Morocco, and more particularly in High and Middle Atlas, this threshold has been set experimentally at three males/trap/ha, although it varies depending on the outbreak. Guenouni [40] clarifies that the estimation must be carried out every 10-15 days on 1000 fruit taken from 50 trees, 20 of which are located on the edges of the orchard. Risk prediction can be measured by the number of insects entrapped and pesticide usage may be determined based on the trap threshold. For the control of aphids, visual inspection of a sample of about 50 trees, well distributed in the plot of two organs/tree is desirable. In the case of spider mites, Sekkat [16] recommends two different action thresholds depending on the season. In the winter season (in January-February), egg laying is very important and there is a high risk of infestation on young shoots. In this case, it is advisable to observe 50 branches at a rate of one branch per tree. If the threshold exceeds $60 \%$ of infested organs, chemical control is required. From spring to fall, it is important to monitor exactly when mite populations begin to invade apple trees, and it is 
recommended that 100 leaves be examined at two leaves/tree and be treated with an acaricide if 40 to $50 \%$ of leaves are infested.

Many biological control methods are available for aphids, scales and spider mites [39]. Unfortunately, biological control was not reported in the provinces. It may be necessary to adopt this method for proper integrated pest control and sustainable management of apple diseases so as to minimize their effects on yields in the short, medium and long term [21]. Farmers reported the challenges in acquiring knowledge on biological control methods. Biological control of insect pests in apple orchards is an important part of integrated pest management programs, requiring more research and application [41]. Farmers should be trained on biological control in the provinces to maintain ecological balance. Some pesticides, especially neonicotinoids, may be harmful to pollinating insects and an alternative approach is highly recommended.

The choice of rootstocks and cultivar is of great importance in apple disease control. Some of these plant materials could be resistant or susceptible to a disease. Resistant apple cultivars can help minimize the use of fungicides and reduce the need for weather forecasting [42]. A few farmers commended the resistance of 'Story' cultivar to apple scab but criticize its susceptibility to apple powdery mildew in the region. 'Golden Delicious' cultivar, which is widely grown in the provinces, was regarded as relatively scab resistant at the beginning of the 20th century but has now become extremely susceptible $[43,44]$. Furthermore, some of the rootstocks, for example MM106, are susceptible to Phytophthora spp. [25]. This implies that varietal resistance is not enough in disease management and may be lost over time.

Having a chemical control for both apple scab and powdery mildew may look economically viable. However, the problem is that some of the active ingredients are more efficient at controlling one of the diseases compared to the other. Moreover, the cycle of the diseases is not the same and might not occur during the same period. However, combined control can be employed through sanitation practices and dormant sprays $[45,46]$. Sanitation practices are a fundamental approach to pest and disease control in an integrated pest management strategy. For chemical control of Phytophthora sp., fosetyl-aluminum completely controlled the disease, and increased growth and fruit yield [47]. The protection could also be provided by combining metalaxyl and by fosetyl- aluminum. For control of fire blight, preventive measures like the use of copper compounds and sanitation practices can be performed frequently in an orchard [17].

For weed infestations in an orchard, farmers did not consider the chemical families in the case of chemical weed control. Moreover, there were only two herbicides mentioned. About $32 \%$ of farmers weeded their orchards manually (Figure 5). Weed interference can be minimized with proper cultural practices and herbicides [48]. Manual weed control facilitates mulching which is a common way to control weeds and reduce resource competition in an orchard. Weed seeds are prevented from germinating and growth of emerging seedlings [49] is suppressed by covering the soil surface with mulch.

An alternative to conventional apple production is an organic production approach. This would help remedy the negative impacts of pesticide use to farmers and their environment. It would also address a consumer concern. Willingness to convert to organic farming was expressed by $40.5 \%$ of farmers (Figure 9). This depends on the establishment of an organic market for their produce and proper training. Even though yields may differ, there are no significant differences in fruit attributes such as taste, flavor, texture and macronutrients between fruit from either production system [50,51]. However, Taylor and Granatstein [52] explain that organic apple production is more costly than the conventional method.

\section{Conclusions}

Undoubtedly, the findings of this survey on apple production practices in the region of Fes-Meknes highlighted that apple trees are subject to plant diseases, insect pests, weed infestation and adverse weather conditions. Meteorological conditions are important environmental factors affecting apple 
quality. With regard to the alternative approaches to chemical control, advocacy is required by FeDAM for the establishment of market facilitation and subsidies in order to motivate farmers who wish to convert to organic farming. The following public interventions should be considered to promote the apple producing sector in the provinces of Ifrane and Sefrou: (1) training farmers to enhance their knowledge about pests and diseases and raise awareness on climate change; (2) educating and supervising pesticide sellers to provide clear and standard information to apple farmers in order to avoid confusion between pesticides and active ingredients; (3) ensuring information transparency and better communication among apple farmers on integrated pest management; and (4) creating a market for organic apple production.

Author Contributions: Conceptualization, R.L.; Data curation, A.M.; Funding acquisition, R.L.; Project administration, M.B.; Supervision, R.L.; Writing—original draft, A.M.; Writing—review \& editing, R.L. and D.M.

Funding: This research received no external funding.

Acknowledgments: The authors express their gratitude to the Phytopathology Unit of the Department of Plant Protection and Environment (Ecole Nationale d'Agriculture de Meknes, Morocco) for the financial support of this work.

Conflicts of Interest: The authors declare no conflict of interest and the funders had no role in the design of the study; in the collection, analyses, or interpretation of data; in the writing of the manuscript, or in the decision to publish the results. The study was compliant with relevant local national standards of Research Ethics.

\section{References}

1. Alami, Y.S. Pommier: Fès-Meknès, un Champion Régional. 2017. Available online: http:/ /www.leconomiste. com/article/1019839-pommier-fes-meknes-un-champion-regional (accessed on 12 May 2018). (In French)

2. Alaoui, S.B. Référentiel pour la Conduite Technique du Pommier (Malus domestica L. Borkh). 2005. Available online: https:/ / www.researchgate.net/publication/281376680_Referentiel_pour_la_Conduite_Technique_ du_pommier_Malus_domestica_L_Borkh (accessed on 22 February 2018). (In French)

3. MADRPM. Conjoncture de la Filière Pomme. 2014. Available online: http:/ /www.agriculture.gov.ma/sites / default/files/141022-note_veille_pommes-sl.pdf (accessed on 1 March 2018). (In French)

4. Courti, I. Monographie de la Région Fés-Meknès. 2016. Available online: http://ma.chm-cbd.net/fesmeknes/prest_region/monographie-de-la-region-fes-meknes (accessed on 9 April 2018). (In French)

5. Anonymous. Pommes: Une Production de 687.000 T au Maroc en 2015-2016. 2017. Available online: https: / www.medias24.com/MAROC/Quoi-de-neuf/177548-Pommes-une-production-de-687.000-T-auMaroc-en-2015-2016.html (accessed on 9 April 2018). (In French)

6. Anonymous. Arboriculture: Région Ifrane. 2017. Available online: http://www.agri-mag.com/2017/06/ arboriculture-region-ifrane/ (accessed on 28 May 2018). (In French)

7. Grove, G.G.; Eastwell, K.C.; Jones, A.L.; Sutton, T.B. 18 Diseases of Apple. In Apples: Botany, Production, and Uses; CABI Publishing: Oxon, UK, 2003; pp. 468-472. [CrossRef]

8. Oukabli, A. Le pommier: Une Culture de Terroir en Zones D'altitude. 2004. Available online: http: / / www.agrimaroc.net/bul115.htm (accessed on 17 February 2018). (In French)

9. Maazouz, S. Les Contraintes à la Culture du Pommier au Maroc. 2016. Available online: http://www. agrimaroc.ma/les-contraintes-a-la-culture-du-pommier-au-maroc/ (accessed on 1 March 2018). (In French)

10. Jirrari, I. Drâa-Tafilalet: La Production des Pommes a Baissé de 40\% en 2016. 2017. Available online: http: / / www.leseco.ma/economie/53680-draa-tafilalet-la-production-des-pommes-baisse-de-40-en-2016.html (accessed on 22 May 2018). (In French)

11. Ministère. Monographie de la Province d'Ifrane. 2016. Available online: http://www.abhatoo.net.ma/ content/download/20999/383300/version/1/file/monographie_province_ifrane.pdf (accessed on 7 June 2018). (In French)

12. Hamdani, M. Monographie des Ressources en Eau de la Région de Fès-Meknès. 2015. Available online: www.memoirepfe.fst-usmba.ac.ma/get/pdf/2988 (accessed on 5 June 2018). (In French)

13. Karamidehkordi, E.; Hashemi, A. Farmers' Knowledge of Integrated Pest Management: A Case Study in the Zanjan Province in Iran. In Proceedings of the ISDA 2010, Montpellier, France, 28 June 2010. 
14. Hmimina, M. La Confusion Sexuelle dans les Vergers à Forte Population Initiale de Carpocapse: Succès, Contraintes et Atouts des Diffuseurs Ginko. 2017. Available online: http:/ /www.agri-mag.com/2017/06/ arboriculture-carpocapse-pommier-et-confusion-sexuelle/ (accessed on 2 June 2018). (In French)

15. Sekkat, A. Aphids of Morocco: Abridged Bio-Ecology of Species Evolving on Crops. Revue Marocaine de Protection des Plantes. 2015. Available online: http:/ / revues.imist.ma/index.php?journal=RMPP\&page= article\&op=view\&path $\% 5 B \% 5 D=3214 \&$ path $\% 5 B \% 5 D=2322$ (accessed on 2 June 2018). (In French)

16. Sekkat, A. Les Acariens du Pommier. 2017. Available online: http://www.agri-mag.com/2017/06/ arboriculture-pommier-acariens / (accessed on 2 June 2018). (In French)

17. Sekkat, A. Traitement D'hiver des Rosacées. 2017. Available online: http:/ /www.agri-mag.com/2017/06/ arboriculture-rosacees-traitement-dhiver/ (accessed on 3 June 2018). (In French)

18. Vicente, C.; Joutei, A.B.; Lebrun, P. Quelles stratégies de lutte contre les acariens ravageurs du pommier au Maroc. Parasitica 2003, 59, 25-41.

19. El Iraqui, S.; Hmimina, M.H. Assessment of control strategies against Cydia pomonella (L.) in Morocco. J. Plant Prot. Res. 2016, 56, 82-88. [CrossRef]

20. Hmimina, M. Les Ravageurs des Arbres Fruitiers: Le Carpocapse des Pommes et des Poires. 2007. Available online: http: / /www.agrimaroc.net/bul158.htm (accessed on 26 February 2018). (In French)

21. Ajaanid, I. Les Méthodes de Lutte Contre les Maladies du Pommier. 2016. Available online: http://www. agrimaroc.ma/la-gestion-des-maladies-du-pommier/ (accessed on 24 February 2018). (In French)

22. MacHardy, W.E. Apple Scab: Biology, Epidemiology, and Management; American Phytopathological Society (APS Press): St. Paul, MN, USA, 1996.

23. Botzen, W.; Bouwer, L.M.; Van den Bergh, J. Climate change and hailstorm damage: Empirical evidence and implications for agriculture and insurance. Resour. Energy Econ. 2010, 32, 341-362. [CrossRef]

24. Oukabli, A. Le Pommier: Facteurs de Choix Variétal pour Investir de Nouveaux Bassins de Production. 2012. Available online: http:/ / www.fellah-trade.com/fr/filiere-vegetale/fiches-techniques / pommier (accessed on 1 March 2018). (In French)

25. Walali, L.D.; Skiredj, A. Fiches Techniques: L'abricotier, le Prunier, le Poirier et le Pommier; Institut Agronomique et Vétérinaire Hassan II: Rabat, Morocco, 2003.

26. Treder, W.; Mika, A.; Buler, Z.; Klamkowski, K. Effects of hail nets on orchard light microclimate, apple tree growth, fruiting and fruit quality. Acta Sci. Polon. Hortorum Cult. 2016, 15, 17-27.

27. Iglesias, I.; Alegre, S. The effect of anti-hail nets on fruit protection, radiation, temperature, quality and profitability of 'Mondial Gala' apples. J. Appl. Hortic. 2006, 8, 91-100.

28. Belay, A.; Recha, J.W.; Woldeamanuel, T.; Morton, J.F. Smallholder farmers' adaptation to climate change and determinants of their adaptation decisions in the Central Rift Valley of Ethiopia. Agric. Food Secur. 2017, 6, 24. [CrossRef]

29. Ali, A.; Erenstein, O. Assessing farmer use of climate change adaptation practices and impacts on food security and poverty in Pakistan. Clim. Risk Manag. 2017, 16, 183-194. [CrossRef]

30. Waibel, H.; Pahlisch, T.H.; Völker, M. Farmers' Perceptions of and Adaptations to Climate Change in Southeast Asia: The Case Study from Thailand and Vietnam. In Climate Smart Agriculture; Springer Nature: New York, NY, USA, 2018; pp. 137-160.

31. Khanal, U. Perception and adaptation of the producers to the impacts of climate change in apple production: An assessment of Mustang district of Nepal. J. Agric. Environ. 2014, 15, 11-17. [CrossRef]

32. Holb, I. Effect of pruning on apple scab in organic apple production. Plant Dis. 2005, 89, 611-618. [CrossRef]

33. Sherwani, A.; Mukhtar, M.; Wani, A.A. Insect pests of apple and their management. In Insect Pest Management of Fruit Crops; Biotech Books: New Delhi, India, 2016; pp. 295-306.

34. Fan, L.; Niu, H.; Yang, X.; Qin, W.; Bento, C.P.; Ritsema, C.J.; Geissen, V. Factors affecting farmers' behaviour in pesticide use: Insights from a field study in northern China. Sci. Total Environ. 2015, 537, 360-368. [CrossRef] [PubMed]

35. Yang, X.; Wang, F.; Meng, L.; Zhang, W.; Fan, L.; Geissen, V.; Ritsema, C.J. Farmer and retailer knowledge and awareness of the risks from pesticide use: A case study in the Wei River catchment, China. Sci. Total Environ. 2014, 497, 172-179. [CrossRef] [PubMed]

36. Sharifzadeh, M.S.; Damalas, C.A.; Abdollahzadeh, G. Perceived usefulness of personal protective equipment in pesticide use predicts farmers' willingness to use it. Sci. Total Environ. 2017, 609, 517-523. [CrossRef] [PubMed] 
37. Van Mele, P.; Cuc, N.T.T.; Van Huis, A. Farmers' knowledge, perceptions and practices in mango pest management in the Mekong Delta, Vietnam. Int. J. Pest Manag. 2001, 47, 7-16. [CrossRef]

38. Sofi, M.A. Major Insect Pests of Apple Grown under Temperate Conditions of Kashmir and Their Integrated Pest Management. Available online: https:/ / www.researchgate.net/publication/315118003 (accessed on 31 January 2017).

39. Paul, A. Insect Pests and Their Management. In The Lentil: Botany, Production and Uses; CABI Publishing: Oxon, UK, 2008.

40. Guenouni, A. Carpocapse du Pommier. 2017. Available online: http://www.agri-mag.com/2017/06/ arboriculture-pommier-carpocapse / (accessed on 2 June 2018). (In French)

41. Zhou, H.; Yu, Y.; Tan, X.; Chen, A.; Feng, J. Biological control of insect pests in apple orchards in China. Boil. Control 2014, 68, 47-56. [CrossRef]

42. Ellis, M.; Ferree, D.; Funt, R.; Madden, L. Effects of an apple scab-resistant cultivar on use patterns of inorganic and organic fungicides and economics of disease control. Plant Dis. 1998, 82, 428-433. [CrossRef]

43. Gessler, C.; Patocchi, A.; Sansavini, S.; Tartarini, S.; Gianfranceschi, L. Venturia inaequalis resistance in apple. Crit. Rev. Plant Sci. 2006, 25, 473-503. [CrossRef]

44. Jamar, L. Innovative Strategies for the Control of Apple Scab (Venturia inaequalis [Cke.] Wint.) in Organic Apple Production. Ph.D. Thesis, Université de Liège, Gembloux, Belgium, 2011.

45. Holb, I.J.; Kunz, S. Integrated Control of Apple Scab and Powdery Mildew in an Organic Apple Orchard by Combining Potassium Carbonates with Wettable Sulfur, Pruning, and Cultivar Susceptibility. Plant Dis. 2016, 100, 1894-1905. [CrossRef]

46. Zalom, F.; Oliver, M.; Osterli, P.; Wallender, W.; Angermann, B.; Werner, I.; Kimball, T.; Deanovic, L.; Wilson, B.; Henderson, J. Monitoring and mitigating offsite movement of dormant spray pesticides from California orchards. Acta Hortic. 2002, 2, 729-735. [CrossRef]

47. Utkhede, R.; Smith, E. Control of Phytophthora crown and root rot of apple trees with fosetyl-aluminium in new plantings. Pest Manag. Sci. 1995, 45, 117-122. [CrossRef]

48. Dittmar, P.J.; Williamson, J.G. Weed Management in Pome Fruit (Apple and Pear); EDIS: Gainesville, FL, USA, 2015.

49. Bond, W.; Turner, R.; Grundy, A. A Review of Non-Chemical Weed Management; HDRA, the Organic Organisation: Coventry, UK, 2003; 81p.

50. Do Amarante, C.V.T.; Steffens, C.A.; Mafra, Á.L.; Albuquerque, J.A. Yield and fruit quality of apple from conventional and organic production systems. Pesquisa Agropecuária Brasileira 2008, 43, 333-340. [CrossRef]

51. Gasparatos, D.; Roussos, P.; Christofilopoulou, E.; Haidouti, C. Comparative effects of organic and conventional apple orchard management on soil chemical properties and plant mineral content under Mediterranean climate conditions. J. Soil Sci. Plant Nutr. 2011, 11, 105-117. [CrossRef]

52. Taylor, M.; Granatstein, D. A cost comparison of organic and conventional apple production in the state of Washington. Crop Manag. 2013, 12. [CrossRef]

(C) 2018 by the authors. Licensee MDPI, Basel, Switzerland. This article is an open access article distributed under the terms and conditions of the Creative Commons Attribution (CC BY) license (http://creativecommons.org/licenses/by/4.0/). 